\title{
Chemical Studies on the Spore Coat Protein of Clostridium perfringens type A
}

\author{
Toshibumi TsuzuKI and Yoshiaki ANDO \\ Hokkaido Institute of Public Health, Sapporo 060, Japan \\ Received May 10, 1985
}

\begin{abstract}
The spore coat protein of Clostridium perfringens type A was solubilized from intact spores by treatment with a mixture of sodium dodecyl sulfate (SDS) and dithiothreitol (DTT) at alkaline $\mathrm{pH}$. About $35 \%$ of the total dry weight of spores was extracted with this treatment. The extracted protein was partially purified by gel filtration. The major component (Fr-B1) is rich in glutamic acid and aspartic acid, as well as half-cystine. SDS-polyacrylamide gel electrophoresis analysis of the Fr-B1 showed a major polypeptide band of a molecular weight of 17,000 .
\end{abstract}

Since the original work of Strange and Dark $^{1)}$ which showed that the spore coat of bacterial spores consists mainly of protein, the chemical features of spore coat protein have been studied extensively by many investigators. $^{2,3)}$ These investigations demonstrated that the coat protein contains at least two components, one is a disulfide-rich protein with a structure resembling that of keratins ${ }^{4,5}$ ) and the other is an alkali-soluble protein. ${ }^{6,7)}$

Most of the results were obtained with Bacillus species, however, little is known about the spore coat protein of Clostridium species. As for the spore coat of Clostridium perfringens, ultrastructural changes in the spore coat of $C$. perfringens type A strain FD-1 spores treated with certain chemical reagents were observed by Labbe et al. ${ }^{8)}$ and Frieben and Duncan ${ }^{9)}$ suggested that the enterotoxin protein of $C$. perfringens type $\mathrm{A}$ is a component of the spore coat proteins.

The spores of a heat-resistant strain of $C$. perfringens type A were capable of germinating with a variety of inorganic and organic ions alone. ${ }^{10)}$ In a previous paper, ${ }^{11)}$ we reported the role of the surface charge in the ionic germination of $C$. perfringens spores and suggested that carboxyl groups in the spore coat protein are the major negatively charged species on the spore surface. This paper describes some chemical properties of the spore coat protein extracted from $C$. perfringens type A spores.

\section{MATERIALS AND METHODS}

Organism and preparation of spores. Clostridium perfringens type A strain NCTC 8238 (Hobbs' serotype 2) was used throughout the experiments. The cultures were maintained in cooked meat medium (Difco). Spores were prepared by the method of Duncan and Strong ${ }^{12)}$ and were freed of vegetative cells by mild ultrasonication followed by extensive washings with deionized water. The spores were suspended in deionized water and stored at $2^{\circ} \mathrm{C}$.

Solubilization of spore coat protein. The clean spores were suspended $(10 \mathrm{mg}$ dry $\mathrm{wt} / \mathrm{ml})$ in a freshly prepared $0.1 \mathrm{M}$ sodium borate buffer ( $\mathrm{pH} 10.0$ ) containing $0.5 \%$ sodium dodecyl sulfate (SDS) and $50 \mathrm{~mm}$ dithiothreitol (DTT), and then incubated at $37^{\circ} \mathrm{C}$ for $2 \mathrm{hr}$ with gentle stirring. ${ }^{13)}$ After centrifugation at $12,000 \times \dot{g}$ for $15 \mathrm{~min}$, the resulting supernatant was removed and regarded as the crude spore coat protein. Part of the supernatant fluid was dialyzed against $50 \mathrm{~mm}$ sodium borate buffer ( $\mathrm{pH} 10.0)$ overnight at room temperature, and protein was determined by the method of Lowry et al. ${ }^{14)}$ using bovine serum albumin as a standard.

Sephadex G-200 gel filtration. Gel filtration was performed on a Sephadex G-200 column $(1.6 \times 100 \mathrm{~cm})$ equilibrated with $50 \mathrm{~mm}$ sodium borate buffer $(\mathrm{pH} 10.0)$ containing $0.1 \%$ SDS and eluted with the same buffer.

SDS-polyacrylamide gel electrophoresis ( $S D S-P A G E)$. SDS-PAGE was performed by a modification of the method in "Polyacrylamide gel electrophoresis laboratory techniques" (Pharmacia Fine Chemicals Co., Ltd.) using a 
4 to $30 \%$ acrylamide gradient slab gel (PAA 4/30, Pharmacia premade, $80 \times 80 \times 4.9 \mathrm{~mm}$ ) in $50 \mathrm{~mm}$ sodium borate buffer $(\mathrm{pH} 10.0$ ) containing $0.1 \%$ SDS. A protein sample was incubated at $45^{\circ} \mathrm{C}$ for $1 \mathrm{hr}$ with an equal volume of $50 \mathrm{~mm}$ sodium borate buffer ( $\mathrm{pH} 10.0$ ) containing $2 \%$ SDS and $10 \%(\mathrm{v} / \mathrm{v}) \quad \beta$-mercaptoethanol. After incubation, the sample was mixed with one drop of glycerol and $0.5 \%(\mathrm{w} / \mathrm{v})$ bromophenol blue in the same buffer, and the mixture was applied to a slab gel. Electrophoresis was carried out first at $300 \mathrm{~V}$ for $10 \mathrm{~min}$ and then at $150 \mathrm{~V}$ until the tracking dye flowed out from the bottom (approximately $2.5 \mathrm{hr}$ ). The gel was stained with Coomassie blue.

Phosphorylase b (molecular weight: 94,000), bovine serum albumin $(67,000)$, ovalbumin $(43,000)$, carbonic anhydrase $(30,000)$, soybean trypsin inhibitor $(20,100)$ and $\alpha$-lactalbumin $(14,400)$ were used as molecular weight markers.

Amino acid analysis. The amino acid composition of the spore coat protein was determined with an automatic amino acid analyzer (Hitachi-835). Samples were hydrolyzed with $6 \mathrm{M} \mathrm{HCl}$ in evacuated sealed Pylex tubes at $110^{\circ} \mathrm{C}$ for $20 \mathrm{hr}$. After removal of $\mathrm{HCl}$ by evaporation in a vacuum desiccator, the residue was redissolved in $1 \mathrm{ml}$ of $0.02 \mathrm{M} \mathrm{HCl}(\mathrm{pH} 2.0)$. The hydrolysates thus obtained were assayed for free amino acids after oxidation of protein with performic acid and hydrolysis. ${ }^{15)}$

Electron microscopy. Native spores or chemically treated spores were suspended in a mixture of $0.5 \mathrm{ml} \mathrm{of} 5 \%$ osmium tetroxide, $1.5 \mathrm{ml}$ of $2.5 \%$ glutaraldehyde and

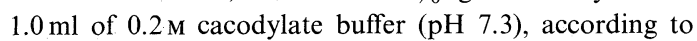
fixation method(a) of Labbe et al. ${ }^{8)}$ After $2 \mathrm{hr}$-fixation, the spores were dehydrated through a graded ethanol series, with two final changes in propylene oxide, and finally embedded in Spurr's resin. ${ }^{16)}$ Sections were cut with an ultramicrotome (LKB) fitted with a glass knife and stained with $1.0 \%$ uranyl acetate and Reynolds' lead citrate. ${ }^{17)}$ The specimens were examined under a JEM-100 CX electron microscope at an accelerating voltage of $80 \mathrm{kV}$.

\section{RESULTS AND DISCUSSION}

\section{Solubilization of spore coat protein}

It is well recognized that the spore coat protein is highly hydrophobic and almost insoluble in diluted aqueous salt solutions. ${ }^{18)}$

Aronson and $\operatorname{Horn}^{19)}$ suggested that the Bacillus cereus $\mathrm{T}$ spore coat may be almost totally solubilized on treatment with a mixture of dithioerythritol (DTE) and SDS at alkaline $\mathrm{pH}$. According to Franceschini and Labbe, ${ }^{13)}$ the DTT-SDS ( $\mathrm{pH}$ 10.0)-extraction method was more effective than three other methods
$(0.05 \mathrm{M}$ DTT, $0.1 \mathrm{~N} \quad \mathrm{NaOH}$ and ureamercaptoethanol) for the solubilization of spore coat protein from $C$. perfringens type A spores.

In this experiment, therefore, spores were extracted with DTT-SDS at pH 10.0 as described under Materials AND Methods. This treatment solubilized coat protein corresponding to about $35 \%$ of the total dry weight of spores.

This value was considerably low compared with that of $46.5 \%$ obtained by Franceschini and Labbe. ${ }^{13)}$ These authors used spores produced in a D-S sporulation medium containing raffinose instead of starch. Since microscopic observations indicated that raffinose-grown spores are remarkably larger in morphological size than starch-grown spores (T. Tsuzuki and Y. Ando, unpublished data), the discrepancy between the two values may be due to differences in chemical features of spores grown in the different sporulation media.

Electron microscopy of a thin-sectioned native spore revealed the presence of the two well defined coat layers, namely, an electron-dense, thinner, inner coat and a less electron-dense, thicker, outer coat (Fig. 1a). On chemical treatment of the native spores to remove the coat protein, both the inner and outer coats were completely removed (Fig. 1b). The coatless spores were found to be still refractile on phase-contrast microscopy.

\section{Fractionation of coat proteins}

When the crude spore coat protein was fractionated by gel filtration on a Sephadex G200 column, two peaks (Fr-A and Fr-B) were seen in the elution profile (Fig. 2). The resulting eluates corresponding to the major peaks, fraction Nos. 27 to 31, of Fr-B were concentrated by ultrafiltration through a membrane, YM-2 (Amicon Co., Ltd.), and then subjected to rechromatography on a Sephadex G-200 column. A very small peak of a high molecular fraction separated from the single main peak of Fr-B1 was seen in the elution pattern (Fig. 3).

The electrophoretic patterns of the main 

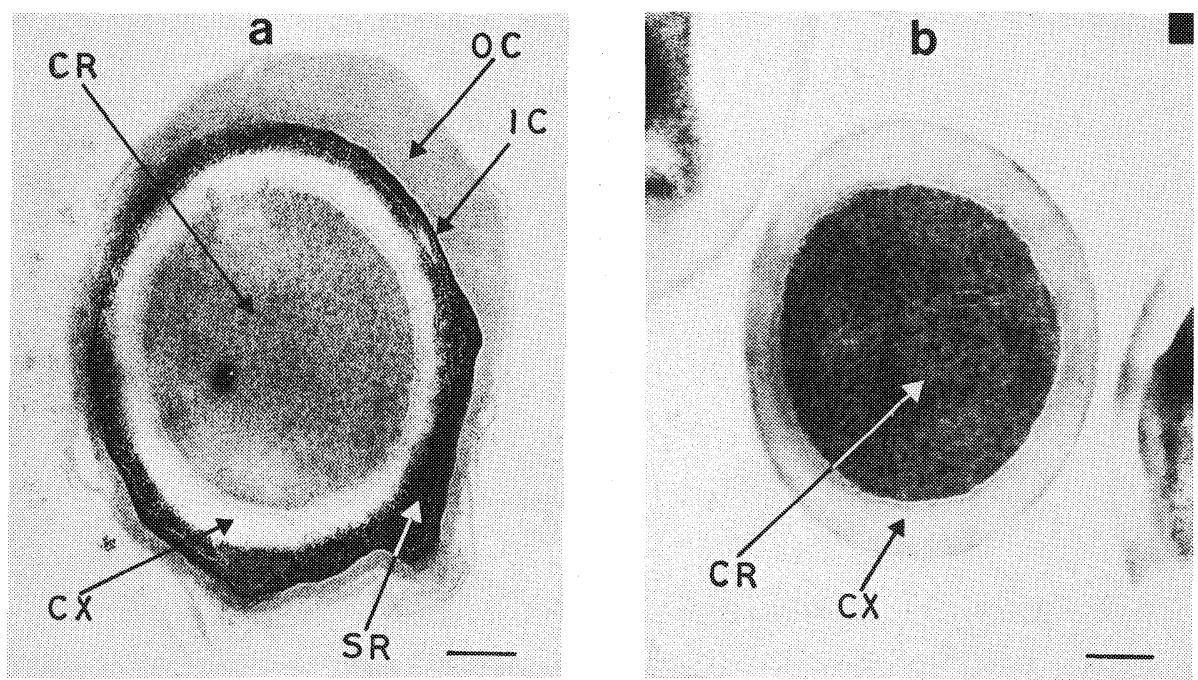

FIG. 1. Electron Micrographs of Thin Sections of C. perfringens Spores.

$a$, intact spore; b, SDS-DTT treated spore. OC, outer coat; IC, inner coat; SR, subcoat region; CX, cortex; $\mathrm{CR}$, core. The bar represents $1 \mu \mathrm{m}$.

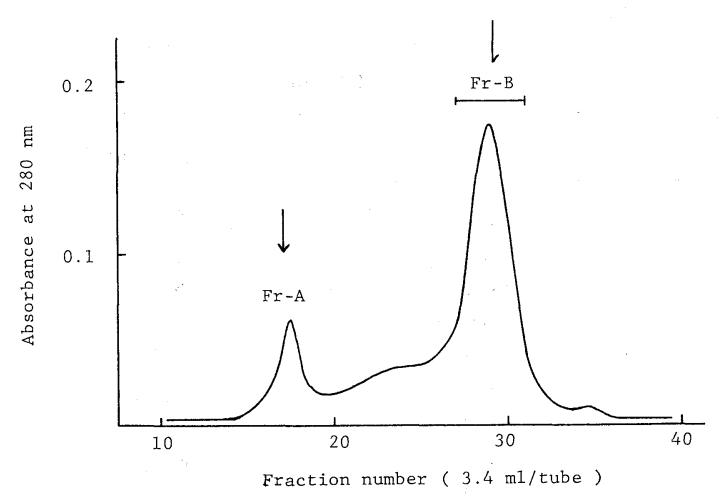

FIG. 2. Gel Filtration of Extracted Spore Coat Protein on Sephadex G-200.

Fractions A and B are indicated.

Arrow, blue dextran; half arrow, cytochrome $c$.

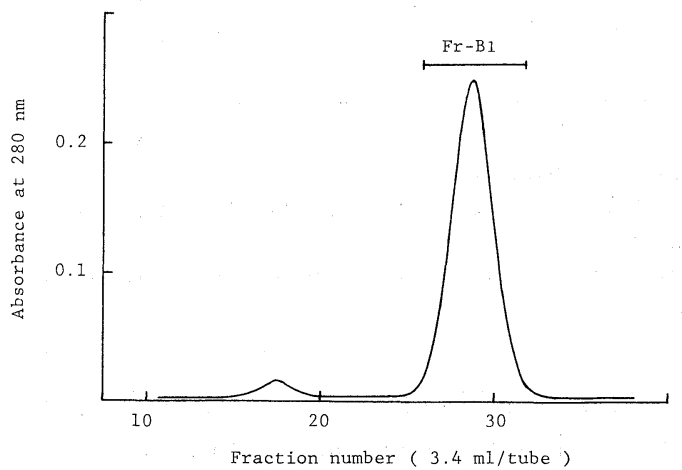

FIG. 3. Rechromatography of Fr-B on Sephadex G-200. peak fraction and several authentic protein samples of known molecular weight are shown in Fig. 4A.

Based on the linear relationship between the electrophoretic mobility and the logarithm of molecular weight of proteins, the molecular weight of the major polypeptide was found to be approximately 17,000 (Fig. 4B).

Aronson and Pandy ${ }^{20,21)}$ reported that the major structural polypeptides of spore coat proteins of $B$. cereus and $B$. subtilis were 13,000 daltons and 8,000 to 12,000 daltons monomers, respectively. In addition to these polypeptides, several other proteins, including enzymes such as cortex lytic enzyme ${ }^{22)}$ or protease $^{23)}$ are present in the coat proteins.

In recent years, Frieben and Duncan ${ }^{9)}$ stated that the enterotoxin of $C$. perfringens is a structural component of the spore coat. They demonstrated various types of enterotoxin-like proteins with different molecular weights of $14,500,23,000$ and 36,000, which were extracted from spores of enterotoxigenic and nonenterotoxigenic strains of $C$. perfringens. We have also verified the existence of enterotoxin in the spore coats of various enterotoxigenic strains, but hardly found a detectable amount of it in the spore coat protein of nonenterotoxigenic strains of this organism. ${ }^{24)}$ 
A

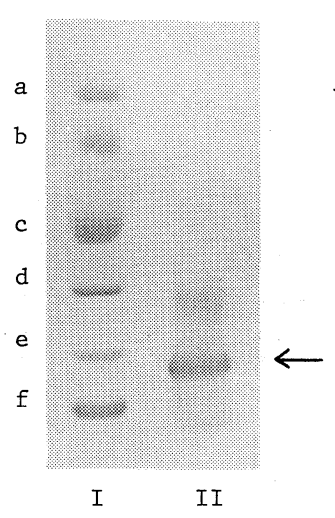

B

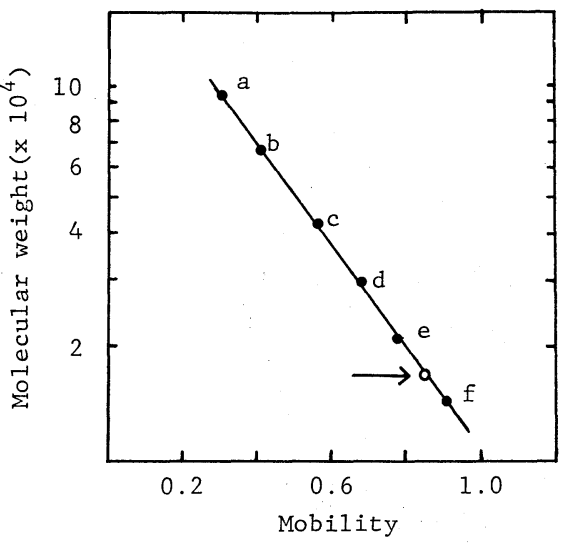

FIG. 4. SDS-PAGE Patterns and Molecular Weight Estimation of Major Spore Coat Protein.

A, SDS-PAGE of molecular weight markers (I) and Fr-B1 in Fig. 3 (II). a, phosphorylase $b$ (M.W. 94,000); b, bovine serum albumin (M.W. 67,000); c, ovalbumin (M.W. 43,000); d, carbonic anhydrase (M.W. 30,000); e, soybean trypsin inhibitor (M.W. 20,100); f, $\alpha$-lactalbumin (M.W. 14,400). B, Estimation of molecular weight of Fr-B1. The position of the major spore coat protein is indicated by an arrow.

Table I. Amino Acid Compositions of the Major Spore Coat Proteins in Comparison with THOSE OF Bacillus SPECIES

\begin{tabular}{|c|c|c|c|c|}
\hline \multirow{2}{*}{ Amino acid } & \multirow{2}{*}{ Fr-B } & \multirow{2}{*}{ Fr-B1 } & \multicolumn{2}{|c|}{ Other data } \\
\hline & & & B. subtilis ${ }^{a}$ & B. megaterium ${ }^{b}$ \\
\hline Lysine & 9.6 & 9.4 & 6.5 & 10.4 \\
\hline Histidine & 2.0 & 1.5 & 2.0 & 1.7 \\
\hline Arginine & 5.2 & 4.7 & 4.9 & 8.8 \\
\hline Aspartic acid & 13.6 & 13.3 & 14.0 & 14.8 \\
\hline Threonine & 2.3 & 2.4 & 5.3 & 4.9 \\
\hline Serine & 3.5 & 3.8 & 8.3 & 6.0 \\
\hline Glutamic acid & 12.1 & 12.4 & 5.7 & 6.2 \\
\hline Proline & 4.7 & 4.3 & + & Trace \\
\hline Glycine & 11.2 & 11.0 & 14.0 & 11.7 \\
\hline Alanine & 4.2 & 4.0 & 8.8 & 10.7 \\
\hline Cystine (half)* & 7.4 & 8.7 & + & - \\
\hline Valine & 3.4 & 3.4 & 4.8 & 3.5 \\
\hline Methionine & 0.4 & 0.6 & 1.4 & 2.4 \\
\hline Isoleucine & 4.0 & 4.0 & 4.2 & 4.5 \\
\hline Leucine & 9.2 & 9.4 & 5.9 & 7.4 \\
\hline Tyrosine & 3.4 & 3.3 & 6.3 & 9.6 \\
\hline Phenylalanine & 3.7 & 3.7 & 5.1 & 2.1 \\
\hline
\end{tabular}

Values are expressed as molar percentages.

* Determined as cysteic acid after performic acid oxidation and hydrolysis.

a Coat protein was extracted from the purified spore coat fraction with $0.1 \mathrm{M}$ sodium borate buffer (pH 10.0) containing $1 \% \mathrm{SDS}$ and $0.1 \mathrm{M}$ DTT at $50^{\circ} \mathrm{C}$ for $30 \mathrm{~min}^{25}$ )

$b$ Coat protein was extracted from lysozyme-digested spores with 0.1 m sodium borate buffer ( $\mathrm{pH} 10.0)$ containing $0.5 \% \mathrm{SDS}, 0.03 \mathrm{M}$ DTT and $0.1 \mathrm{M} \mathrm{NaCl}$ at $37^{\circ} \mathrm{C}$ for $2 \mathrm{hr}^{26)}$

\section{Amino acid analysis}

The amino acid compositions of the partially purified coat proteins (Fr-B and Fr-B1) are shown in Table I, which also includes the results of amino acid analyses in other laboratories $^{25,26)}$ for comparison. 
The Fr-B1 protein was found to be relatively rich in glutamic acid and aspartic acid, the two acidic amino acids constituting about 25 percent of the total amino acids. While, the amounts of aspartic acid, glycine and alanine are high in Bacillus species. There are significant differences in the molar amounts of several amino acids such as glutamic acid, half-cystine and proline. The amount of glutamic acid in the Fr-B1 protein is twice that in Bacillus species. In addition, the Fr-Bl protein consists of keratin-like proteins. The synthesis of this sort of proteins and their packaging into the morphologically distinct coat layers are necessary events in sporulation for a protective coat assembly. ${ }^{27)}$

Thus, outer coat proteins should be enriched selectively with half-cystine residues. These facts are consistent with that outer coat layers are much thicker than inner coat layers, as observed in electron micrograph sections.

\section{REFERENCES}

1) R. E. Strange and F. A. Dark, Biochem. J., 62, 459 (1956).

2) M. Kondo and J. W. Foster, J. Gen. Microbiol., 47, 257 (1967)

3) A. I. Aronson and P. C. Fitz-James, Bacteriol. Rev., 40, 360 (1976).

4) V. Vinter, "Spores II," ed. by H. O. Halvorson, Minneapolis 15, Minn., Burgess Publishing Co., 1961, p. 127.

5) H. Kadota, K. Iijima and A. Uchida, Agric. Biol. Chem., 29, 870 (1965).

6) G. W. Gould, J. M. Stubbs and W. L. King, J. Gen.
Microbiol., 60, 347 (1970).

7) T. Nishihara, M. Tomita, N. Yamanaka and M. Kondo, Microbiol. Immunol., 24, 105 (1980).

8) R. G. Labbe, R. R. Reich and C. L. Duncan, Can. J. Microbiol., 24, 1526 (1978).

9) W. R. Frieben and C. L. Duncan, Eur. J. Biochem., 39, 393 (1973).

10) Y. Ando, Jpn. J. Microbiol., 18, 433 (1974).

11) Y. Ando and T. Tsuzuki, J. Gen. Microbiol., 130, 267 (1984).

12) C. L. Duncan and D. H. Strong, Appl. Microbiol., 16, 412 (1968).

13) T. J. Franceschini and R. G. Labbe, Microbios, 25, 85 (1979).

14) O. H. Lowry, N. J. Rosebrough, A. L. Farr and R. J. Randall, J. Biol. Chem., 193, 265 (1951).

15) S. Moore, J. Biol. Chem., 238, 235 (1963).

16) A. R. Spurr, J. Ultrastruct. Res., 26, 31 (1969).

17) F. S. Reynolds, J. Cell. Biol., 17, 208 (1963).

18) A. Kornberg, J. A. Spudich, D. L. Nelson and M. P. Deutsher, Ann. Rev. Biochem., 37, 51 (1968).

19) A. I. Aronson and D. Horn, "Spores V," ed. by H. O. Halvorson, R. Hanson and L. L. Campbell, Am. Soc. Microbiol., 1972, p. 19.

20) A. I. Aronson and N. K. Pandy, "Spores VII," ed. by G. Chambliss and J. C. Vary, Am. Soc. Microbiol., 1978, p. 54.

21) A. I. Aronson and N. K. Pandy, J. Bacteriol., 137, 1208 (1979).

22) O. P. Srivastava and P. C. Fitz-James, Can. J. Microbiol., 27, 408 (1981).

23) A. I. Aronson and P. C. Fitz-James, J. Bacteriol., 123, 354 (1975).

24) Y. Ando, T. Tsuzuki, H. Sunagawa and S. Oka, Microbiol. Immunol., 29, 317 (1985).

25) T. Mitani and H. Kadota, J. Gen. Appl. Microbiol., 22, 51 (1976).

26) T. Ichikawa, K. Yamanishi, K. Watabe, T. Nishihara and M. Kondo, J. Gen. Microbiol., 128, 2149 (1982).

27) A. I. Aronson and P. C. Fitz-James, J. Mol. Biol., 33, 199 (1968). 